This item was submitted to Loughborough's Research Repository by the author.

Items in Figshare are protected by copyright, with all rights reserved, unless otherwise indicated.

\title{
Asymmetric total synthesis of (-)-erogorgiaene and its C11 epimer and investigation of their antimycobacterial activity
}

\section{PLEASE CITE THE PUBLISHED VERSION}

http://dx.doi.org/10.1002/chem.201602440

\section{PUBLISHER}

(c) Wiley

\section{VERSION}

AM (Accepted Manuscript)

\section{PUBLISHER STATEMENT}

This work is made available according to the conditions of the Creative Commons Attribution-NonCommercialNoDerivatives 4.0 International (CC BY-NC-ND 4.0) licence. Full details of this licence are available at: https://creativecommons.org/licenses/by-nc-nd/4.0/

\section{LICENCE}

CC BY-NC-ND 4.0

\section{REPOSITORY RECORD}

Incerti-Pradillos, Celia A., Mikhail A. Kabeshov, Paul O'Hora, Sergei A. Shipilovskikh, Aleksandr E. Rubtsov, Vera A. Drobkova, Svetlana Yu Balandina, and Andrei V. Malkov. 2019. "Asymmetric Total Synthesis of (-)erogorgiaene and Its C11 Epimer and Investigation of Their Antimycobacterial Activity". figshare. https://hdl.handle.net/2134/22370. 


\title{
Asymmetric Total Synthesis of (-)-Erogorgiaene and Its C11 Epi- mer and Investigation of Their Antimycobacterial Activity
}

\author{
Celia A. Incerti-Pradillos ${ }^{[a]}$, Mikhail A. Kabeshov ${ }^{[a]}$, Paul S. O'Hora ${ }^{[a]}$, Sergei A. Shipilovskikh ${ }^{[a, b]}$, \\ Aleksandr E. Rubtsov ${ }^{[b]}$, Vera A. Drobkova ${ }^{[b]}$, Svetlana Yu. Balandina ${ }^{[b]}$, and Andrei V. Malkov ${ }^{[a]_{*}}$
}

\begin{abstract}
A short, 9-step, highly enantioselective synthesis of (-)erogorgiaene and its C11 epimer is reported. The key stereochemistry controlling steps involve catalytic asymmetric crotylation, anionic oxy-Cope rearrangement and cationic cyclization. (-)Erogorgiaene exhibited promising antitubercular activity against multidrug resistant strains of $M$. tuberculosis.
\end{abstract}

\section{Introduction}

For many years, natural products served as an inspirational source for developing new drugs. Now, with antibiotics losing their effectiveness at an alarming rate, there is an urgent need to find new antibacterial leads to tackle this problem. Diterpenoids bearing a serrulatane (biflorane) skeleton exhibited a wide range of useful biological properties including promising antimycobacterial activity. ${ }^{[1]}$ Selected representatives of serrulatane metabolites found in the marine gorgonian Pseudopterogorgia elisabethae (1-4) and in terrestrial plants, e.g. Mexican evergreen shrub Leucophyllum frutescens (5) and Australian Eremophila (6), are shown in Figure 1. Inspection of the stereochemical elements of these compounds reveals that the diterpenes isolated from the sea organisms differ from the terrestrial counterparts by the relative configuration at C-11. Additionally, these two groups of serrulatane diterpenes generally belong to the opposite enantiomeric series, although the levorotatory enantiomer of 1 was isolated from a brown alga (Dictyota dichotoma). ${ }^{[2]}$

The relatively simple structures and potent biological activity of serrulatane diterpenes that in many instances is augmented by the low abundance and scarcity of supply from their natural sources make them attractive synthetic targets for exploring their therapeutic potential. However, the lack of functional groups near the stereogenic centres in the predominantly hydrocarbon serrulatane core represents a significant challenge for stereose-

[a] Dr. C. A. Incerti-Pradillos, Dr. M. A. Kabeshov, Dr. P. S. O'Hora, S. A. Shipilovskikh, and Prof. Dr. A. V. Malkov

Department of Chemistry

Loughborough University

Loughborough, LE11 3TU, UK

Fax: +44 (0)1509 223925

E-mail: A. Malkov@lboro.ac.uk

[b] S. A. Shipilovskikh, Dr. V. A. Drobkova, S. Yu. Balandina and Dr. A E. Rubtsov

Department of Chemistry

Perm State University

Bukireva 15, Perm, 614990, Russia

Supporting information for this article is given via a link at the end of the document lective synthesis. The successful strategies for controlling stereochemistry in the total synthesis of this family of diterpenes include chiral pool, ${ }^{[3]}$ chiral reagents/chiral substrates, ${ }^{[4]}$ and asymmetric catalysis. ${ }^{[5]}$ In the case of erogorgiaene 1 , the synthesis usually required 11 steps or more, for a notable exception of the 8-step convergent sequence developed by Aggarwal, ${ }^{[\mathrm{b}]}$ which also provided access to other three diastereoisomers of 1. Recently, we reported on enantioselective synthesis of (-)elisabethadione $\mathbf{3}$, where the key stereochemistry defining steps included (i) catalytic asymmetric crotylation, (ii) anionic oxy-Cope rearrangement $(\mathrm{AOC})$ and (iii) cationic cyclization. ${ }^{[5 \mathrm{~d}]}$ Herein, we present extension of this strategy to a wider range of serrulatane diterpenes with a detailed insight into the stereochemistry of the AOC. The generality of the method is illustrated by a short, highly enantioselective synthesis of both C-11 diastereoisomers of erogorgiaene $\mathbf{1}$ followed by investigation into their activity against Mycobacterium tuberculiosis including multidrug resistant strains.

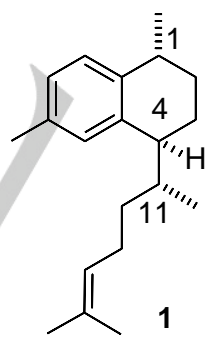

(-)-Erogorgiaene<smiles>CC(C)=CCC[C@H](C)[C@H]1CC[C@@H](C)c2cc(O)c(C)cc21</smiles>

(+)-7-Hydroxyerogorgiaene<smiles>CC(C)=CCCC(C)[C@H]1CC[C@@H](C)c2c1cc(C)c(O)c2O</smiles>

seco-Preudopterosin aglycone<smiles>CC(C)=CCC[C@H](C)[C@H]1CC[C@@H](C)c2c(O)cc(C)cc21</smiles>

(-)-Leubethanol<smiles>CC(C)=CCC[C@H](C)[C@H]1CC[C@@H](C)C2=C1C(=O)C(C)=C(O)C2=O</smiles>

(+)-Elisabethadione<smiles>CC(C)=CCC[C@H](C)[C@H]1CC[C@@H](C)c2c(O)cc(CO)cc21</smiles>

(-)-8,19-dihydroxyserrulat-14-ene
Figure 1. Serrulatane metabolites.

\section{Results and Discussion}

Retrosynthetic analysis of erogorgiaene 1 (Scheme 1) identifies a-methylcinnamaldehyde $\mathbf{1 1 b}$ as the starting material, which 
undergoes asymmetric allylation with 10 to afford alcohol 9 followed by the anionic oxy-Cope rearrangement into 8 that installs two out of three stereogenic centers of the serrulatane skeleton. Ensuing cationic cyclization after side chain extension delivers the final stereogenic center (7).<smiles>C=CCC[C@H](C)[C@H]1CC[C@@H](C)c2ccc(C)cc21</smiles><smiles>[X]c1cccc(C(CC=CC)C(C)C=O)c1[X]</smiles>

8a, $R=X=H$, 8b, $R=M e, X=H$ 8c, $R=M e, X=B r$<smiles>[X]c1cccc(/C=C(\C)C=O)c1[R]</smiles>

11a, $R=X=H$, 11b, $\mathrm{R}=\mathrm{Me}, \mathrm{X}=\mathrm{H}$ 11c, $\mathrm{R}=\mathrm{Me}, \mathrm{X}=\mathrm{Br}$ asymmetric crotylation

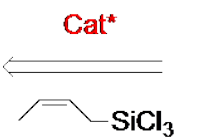

10

crotylion
Scheme 1. Retrosynthetic analysis of erogorgiaene 1.

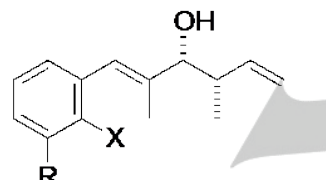

9a, $\mathrm{R}=\mathrm{X}=\mathrm{H}$,

9b, $R=M e, X=H$

9c, $R=M e, X=B r$
oxy-Cope rearrang.
Catalytic methods for highly enantio- and diastereoselective crotylation of unsaturated aldehydes mediated by chiral Lewis bases have been reported from this laboratory and by others. ${ }^{[5 \mathrm{~d},}$ 6] Therefore, the initial studies for assessing feasibility of this sequence were focused on the stereochemical course of the $A O C$ rearrangement and subsequent transformations. The model experiments were carried out with alcohols syn-9a and anti-14 that are conveniently synthesized in diastereomerically pure form by crotylation of a-methylcinnamaldehyde 11a with Zcrotyltrichlorosilane 10 and its $E$-isomer 13 , respectively ${ }^{[5 d, 6]}$ (Scheme 2). The enolate resulting from the rearrangement was protonated with $\mathrm{MeOH}$ at $-78^{\circ} \mathrm{C}$ and the intermediate aldehyde, without isolation, was subjected to Wittig alkenylation to furnish 15a. Clearly, syn-9a exhibited much better stereoselectivity. Note that the $\mathrm{AOC}$ is responsible for the formation of $\mathrm{C} 4$ and the geometry of the alkene $(E / Z)$ in $15 \mathbf{a}$, whereas C11 is formed post rearrangement, in the protonation of the enolate.

The charge-accelerated [3,3] sigmatropic process is likely to proceed via a chair-like transition state, however chirality transfer in the $A O C$ is not straightforward and strongly depends on the substitution pattern of the substrate.$^{[7]}$ Analysis of the stereochemical course of the AOC is presented in Scheme 3.

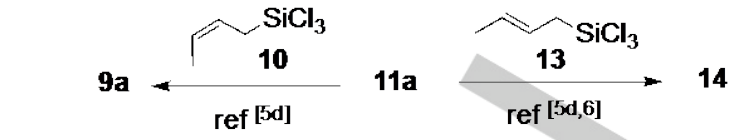<smiles>C=C[C@@H](O)[C@H](O)/C(C)=C/c1ccccc1</smiles>

\section{$(3 R, 4 S)-9 a$}<smiles>C=CC(C)C(O)C(C)=CC</smiles>

Ph

$(3 S, 4 S)-14$

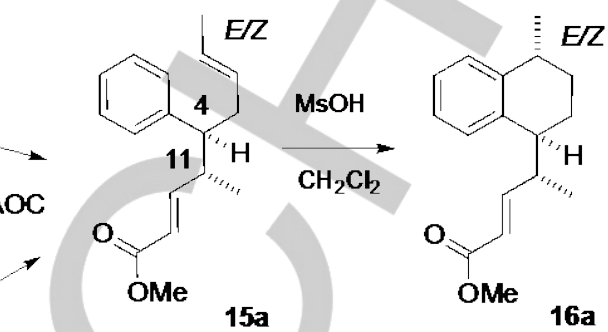

From 9a: $\quad$ From 9a:

$E / Z$ 25:1, d.r. 2.5:1

From 14:

$E / 2$ 11:1, C11 d.r. 1.4:1

From 14:

AOC: i) $\mathrm{KH},[18] \mathrm{C}-6 \mathrm{THF}, 50^{\circ} \mathrm{C}$; ii) $\mathrm{MeOH},-78^{\circ} \mathrm{C}$; ii) $\mathrm{Ph}_{3} \mathrm{PCHCO}_{2} \mathrm{Me}$

The reactions were carried out with racemic substrates; the asolute configurations relate to that of the natural product $(-)_{1}-1$ and serve to ilustrate the stereochemical course of the reactions

Scheme 2. Model studies of anionic oxy-Cope rearrangement.

In the rearrangement of syn-9a, the two possible transition states $\mathbf{A}$ and $\mathbf{B}$ will result in the respective products $\mathbf{1 7}$ and $\mathbf{1 8}$ with a different alkene geometry and, importantly, with the opposite absolute configuration at the benzylic centre. However, the TS B is clearly disfavored due to the axial arrangement of the three adjacent substituents: the two methyl groups and the alkoxide. Therefore, enolate 17 is formed preferentially $(\mathbf{1 7 / 1 8}$ 25:1). Both chair-like transition states $\mathbf{C}$ and $\mathbf{D}$ resulting from anti-14 feature two axial and one equatorial substituent, however TS $\mathbf{D}$ appears to be much less favourable due to the adverse 1,3-diaxial interactions between the methyl groups. The observed lack of stereoselectivity in this instance (17'/18' 3:1) suggests that a boat TS might be involved. ${ }^{[7 a]}$

It is also pertinent to note that to produce the same C-4 enantiomer of 17/17', alcohols syn-9a and anti-14 should come from the opposite enantiomeric series (Schemes 2 and 3).
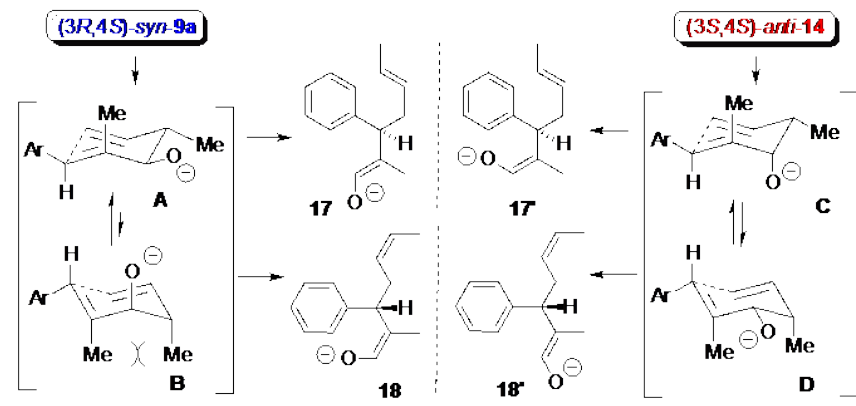

Scheme 3. Stereochemistry of anionic oxy-Cope rearrangement. 
As a consequence, to enable an efficient transfer of chirality in the asymmetric variant of the $\mathrm{AOC}$, it is a prerequisite to employ diastereomerically pure $\mathbf{9 a}$ since asymmetric crotylation is usually face-selective and affords syn and anti isomers (9 and 14) with the same absolute configuration of the alcohol. ${ }^{[5 d]}$

Furthermore, $E$ configuration of the double bond in 17 (and 15a) is crucial for achieving 1,4-trans tetralin structure $\mathbf{1 6 a}$ in the subsequent cationic cyclization (Scheme 2, cf Figure 1), as Zalkene 18 appears to favour the respective 1,4-cis tetralin. ${ }^{[5 d, 8]}$

While the engineered substitution pattern in $9 \mathrm{a}$ ensures the high stereochemical fidelity in the formation of the C-4 stereogenic center during the $\mathrm{AOC}$, formation of the $\mathrm{C}-11$ relies on a faceselective protonation of the potassium enolate resulting from the rearrangement. Methanol quenching at $-78{ }^{\circ} \mathrm{C}$ furnishes a nearly equimolar mixture of isomeric syn-19 and anti-20. Preliminary calculations at the semi-empirical level ${ }^{[9]}$ identified two major conformations $\mathbf{E}$ and $\mathbf{F}$ (Scheme 4) of the intermediate enolate (modelled as enol). A less than $0.3 \mathrm{kcal} / \mathrm{mol}$ energy difference between $\mathbf{E}$ and $\mathbf{F}$ correlates with the observed lack of stereoselectivity in the protonation. A brief optimisation of quenching conditions under kinetic control revealed that protonation of the enolate with a bulkier $2,4,6$-tri-tert-butylphenol at $-78^{\circ} \mathrm{C}$ gave an improved 2.5:1 d.r. (Scheme 2). It is worth noting that equilibration of a 2:1 19/20 mixture with MeONa in MeOH/THF at rt for 12 $\mathrm{h}$ resulted in a 1:1.3 mixture favoring 20. serves as a blocking group to eliminate the issue of regioselectivity in the cationic cyclization. Bromine has a successful record of being employed as a protecting group in total synthesis of natural products on a large scale; $;^{[10]}$ it can be readily removed by reduction once it has served its purpose. Provided the debromination could be combined with other reduction process, the revised strategy would not affect the overall number of steps in the synthesis.

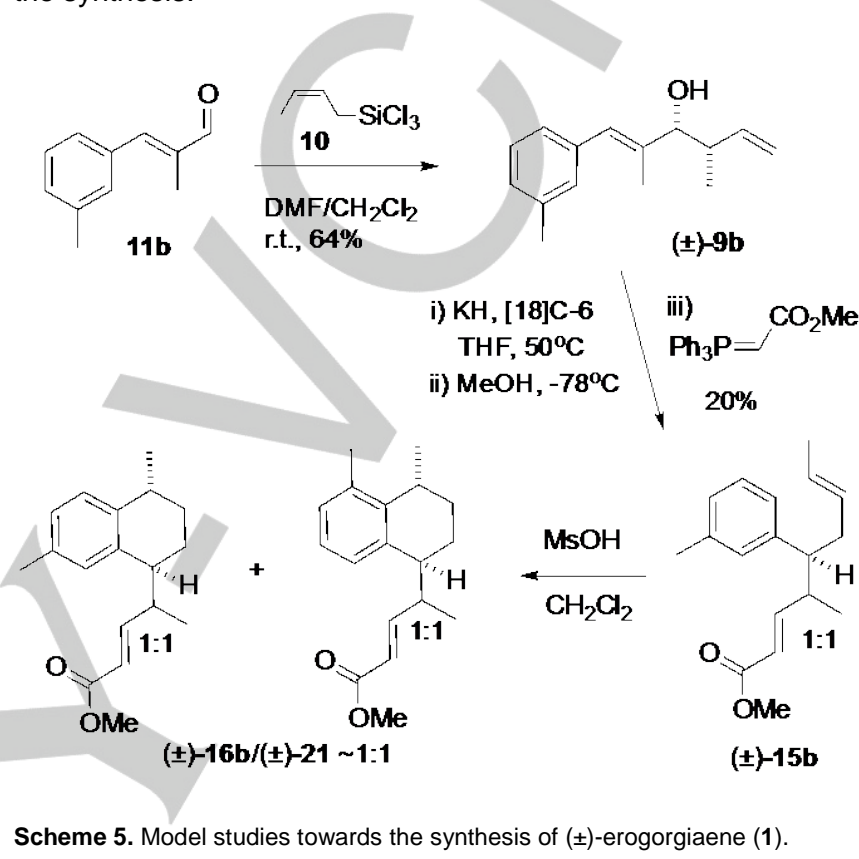

The route commenced with the synthesis of 11c by aldol condensation of commercially available aldehyde $\mathbf{2 2}$ with propional (70\%). Asymmetric crotylation of $11 \mathrm{c}$ with 10 catalysed by our recently developed bis- $N$-oxide $(-)-12^{[5 d]}(2$ mol\%) in propionitrile at $-60{ }^{\circ} \mathrm{C}$ on a $5 \mathrm{mmol}$ scale furnished homoallylic alcohol syn-(-)-9c in 72\% yield and excellent 99:1 er (d.r. > 25:1). The AOC rearrangement was carried out following the conditions described for alcohol 9a, except the reaction was performed in DME at RT. Quenching the resulting enolate with 2,4,6-tri-tert-butylphenol at $-78{ }^{\circ} \mathrm{C}$ gave a $2: 1$ ratio of $\mathrm{C}$ - 11 diastereoisomers. To minimise manipulation of the oxidationprone aldehyde and to avoid epimerisation at C-11, the crude aldehyde was subjected to Horner-Wadsworth-Emmons alkenylation conditions $^{[11]}$ to furnish unsaturated ester $15 \mathrm{c}(81 \%$ over 2 steps). The diastereoisomers were not separable at this point therefore the synthesis continued with the mixture. Ester $15 \mathrm{c}$ was submitted to the cationic cyclisation with $\mathrm{MeSO}_{3} \mathrm{H}$ to produce trans-tetraline $\mathbf{1 6 c}$ in $83 \%$ yield and good stereoselectivity (dr 14:1). With all the stereocentres in place, the next task was to reduce the unsaturated ester to the saturated alcohol and remove $\mathrm{Br}$ from the aromatic ring. After some experimentation it was found that continuous flow hydrogenation in methanol using $\mathrm{H}$-cube $(2.0 \mathrm{~mL} / \mathrm{min}, 20 \mathrm{bar}, 40$ $\left.{ }^{\circ} \mathrm{C}, 4 \mathrm{~h}\right)$ equipped with a $10 \% \mathrm{Pd} / \mathrm{C}$ catalyst cartridge accomplished both the double bond reduction and debromination. The solvent was replaced for DCM and the 
saturated ester was reduced with DIBAL-H into primary alcohol 7 in $70 \%$ overall yield. Preparative HPLC separation of the diastereoisomers furnished pure (-)-7 and its C-11 epimer (-)-7a Dess-Martin oxidation of (-)-7 led to the respective aldehyde in $84 \%$ yield. Finally, Wittig alkenylation afforded (-)-erogorgiaene 1 (dr 12:1) in 80\% yield exhibiting optical rotation $[\alpha]_{D}=-25.5(c$ $0.52, \mathrm{CHCl}_{3}$ ) that is in agreement with the value for the natural product isolated from a brown alga (Dictyota dichotoma): $[\alpha]_{D}=-$ 28.0 (c $\left.0.05, \mathrm{CHCl}_{3}\right)^{[2]}$ and the absolute value of the dextrorotatory enantiomer from Pseudopterogorgia elisabethae: $[\alpha]_{\mathrm{D}}=+24.4\left(\mathrm{c} \mathrm{3.2}, \mathrm{CHCl}_{3}\right) \cdot{ }^{[1 \mathrm{a}]}$ Synthesis of the $\mathrm{C}-11$ epimer (-)1a ( $\mathrm{dr} 7: 1)$ from the respective alcohol (-)-7a was completed through the same two-step sequence.

According to an earlier report, ${ }^{[1 a]}(+)$-erogorgiaene 1 exhibited promising activity against Mycobacterium tuberculiosis $\mathrm{H}_{37} \mathrm{Rv}$ (96\% growth inhibition at $12.5 \mu \mathrm{g} / \mathrm{mL}$ ). Due to the minute quantities of the isolated material, it has not been further investigated. C-11 epimer (-)-1a has the same relative and absolute configuration as (-)-leubethanol $\mathbf{5}$, which showed a potent activity against both drug-sensitive and multidrug resistant (MDR) strains at minimal inhibitory concentrations (MIC) in the range of 6.25-12.5 $\mu \mathrm{g} / \mathrm{mL}^{[12]}$ Therefore, with the two diastereoisomers ()-1 and (-)-1a in hand, we next evaluated their antitubercular activity against two clinical isolates of $M$. tuberculosis, one of which showed sensitivity to isoniazid and rifampicin, the first-line anti-TB drugs, the other exhibited multidrug resistance. Selected data are presented in Table 1.

Table 1. Antimycobacterial activity of (-)-1 and (-)-1a

\begin{tabular}{llll}
\hline \multirow{2}{*}{ Entry } & \multirow{2}{*}{ Compound } & \multicolumn{2}{c}{ MIC $(\mu \mathrm{g} / \mathrm{mL})$} \\
\cline { 3 - 4 } & & $\begin{array}{c}\text { Susceptible to } \\
\text { TB drugs }\end{array}$ & MDR Strain \\
\hline 1 & $(-)-\mathbf{1}$ & 31,25 & 125,0 \\
2 & $(-)-\mathbf{1 a}$ & 62,5 & 250,0 \\
\hline
\end{tabular}

The results revealed that (-)-1 was twice as active as its C-11 epimer (-)-1a against both TB strains. Comparison with the literature data for erogorgiaene 1 indicates that the dextrorotatory enantiomer (+)-1 isolated from the octocoral Pseudopterogorgia elisabethae showed somewhat higher activity than its enantiomer (-)-1 synthesised in this work. High potency of (-)leubethanol 5 seems to indicate the importance of the hydroxyl group in the position 8 of the aromatic ring for antitubercular activity. It is worth noting that the both $\mathrm{C}-11$ epimers induced growth inhibition of the MDR strain and can serve as leads for further development.

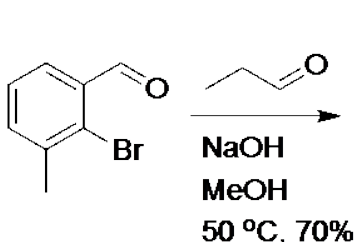

22<smiles>CC(C)=CCC[C@H](C)C1CC[C@H](C)c2ccc(C)cc21</smiles>

1) Dess-Martin

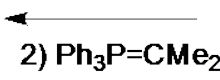

$67 \%$ over 2 step
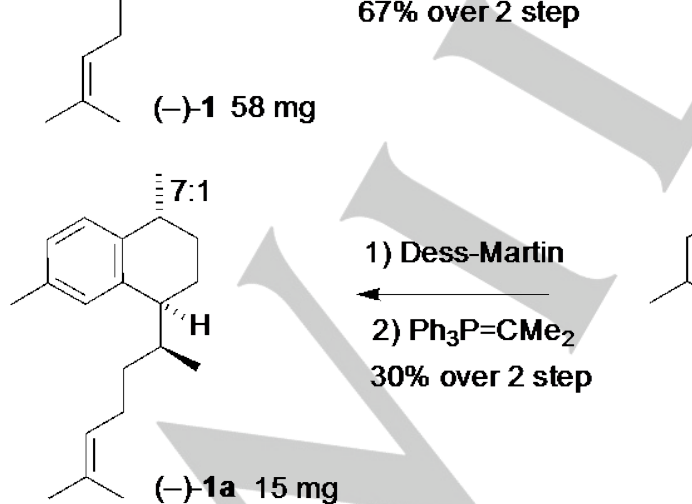

1) Dess-Martin

2) $\mathrm{Ph}_{3} \mathrm{P}=\mathrm{CMe}_{2}$

$30 \%$ over 2 step

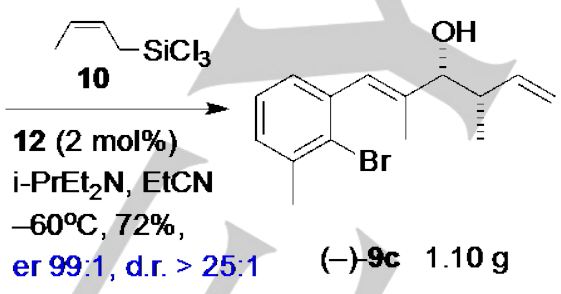

$12: 1$<smiles>CCC1CCC(C(C)C)c2cc(C)ccc21</smiles>

$\mathrm{OH}$

(-)-7 $104 \mathrm{mg}$

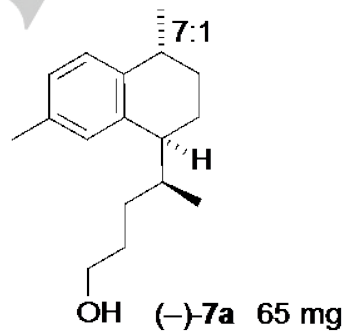

1i) $\mathrm{KH},[18] \mathrm{C}-6$, rt ii) $\mathrm{ArOH},-78^{\circ} \mathrm{C}$

2) $\mathrm{O} \quad \mathrm{CO}_{2} \mathrm{Et}$ $(\mathrm{EtO})_{2} \mathrm{P}-$

$81 \%$ over 2 steps<smiles>[Z1]C(/C=C/C(=O)OCC)[C@H](C/C=C/C)c1cccc(C)c1Br</smiles>

15c $1.10 \mathrm{~g}$
$\mathrm{MsOH}, \mathrm{CHCl}_{3}$,
$40^{\circ} \mathrm{C}, 83 \%$

i) $\mathrm{Pd} / \mathrm{C}, \mathrm{H}$-Cube

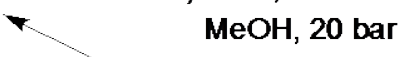

$40^{\circ} \mathrm{C}$

ii) DIBAL-H

$70 \%$

prep HPLC<smiles>[Z1]C(/C=C/C(=O)OCC)[C@H]1CC[C@H]([Y14])c2ccc(C)c(Br)c21</smiles>

16c $570 \mathrm{mg}$ 


\section{Conclusions}

A short, 9-step synthesis of natural (-)-erogorgiaene $(10.5 \%$ overall yield) and its C-11 epimer from a commercially available precursor has been accomplished though a sequence of simple transformations. The key reactions for introducing stereogenic centers include (i) highly enantioselective catalytic crotylation, (ii) anionic oxy-Cope rearrangement and (iii) cationic cyclisation. In the latter instance, protection strategy was seamlessly integrated into the synthesis without altering the number of steps. The compounds showed promising activity against clinical isolates of M. tuberculosis including multidrug resistant strain. Ready access to a-methyl cinnamaldehydes with various substitution patterns in the aromatic ring opens the door to the synthesis of natural and unnatural analogues of these diterpenes for biological evaluation.

\section{Experimental Section}

\section{General Methods and Materials.}

The NMR spectra were recorded in $\mathrm{CDCl}_{3},{ }^{1} \mathrm{H}$ at $400 \mathrm{MHz}$ and ${ }^{13} \mathrm{C}$ at 100.6 MHz with chloroform- $\mathrm{d}_{1}\left(\delta 7.26,{ }^{1} \mathrm{H} ; \delta 77.0,{ }^{13} \mathrm{C}\right)$ as internal standard unless otherwise indicated. Various 2D-techniques and DEPT experiments were used to establish the structures and to assign the signals. The IR spectra were recorded in $\mathrm{KBr}$ disc unless otherwise indicated. The mass spectra were recorded in a positive or negative ion mode using electrospray ionisation (ESI) from methanol or acetonitrile. All reactions were performed under an atmosphere of dry, oxygen-free nitrogen in oven-dried glassware. Yields are given for isolated products showing one spot on a TLC plate and no impurities detectable in the NMR spectrum. The identity of the products prepared by different methods was checked by comparison of their NMR, IR, and MS data and by the TLC behavior. All chromatographic manipulations used silica gel as the absorbent. Reactions were monitored by thin layer chromatography (TLC) on aluminum backed plates with Merck Kiesel 60 F254 silica gel. TLCs were either visualized by UV radiation at a wavelength of $254 \mathrm{~nm}$, or stained by exposure to an ethanolic solution of phosphomolybdic acid or potassium permanganate aqueous solution, following by charring where appropriate. Purification by column chromatography was carried out using Merck Kiesel $60 \mathrm{H}$ silica adsorbent. All solvents and reagents for the reactions were of reagent grade and were dried and distilled under nitrogen immediately before use as follows: tetrahydrofuran was distilled under a nitrogen atmosphere from the sodium/benzophenone ketyl radical, propionitrile and dichloromethane were freshly distilled from $\mathrm{CaH}_{2}$. Petroleum ether refers to the fraction boiling in the range $40-60{ }^{\circ} \mathrm{C}$. Synthesis of Z-crotyltrichlorosilane $\mathbf{1 0}$ and catalyst $\mathbf{1 2}$ was described by us earlier; ${ }^{[5 b]}$ literature protocols were used for synthesising known aldehydes $11 \mathbf{a}^{[13]}$ and $16^{[14]}$

Asymmetric synthesis of (-)-erogorgiane (1) and its C-11 epimer (1a) by a revised strategy.

(E)-3-(2-bromo-3-methylphenyl)-2-methylacrylaldehyde (11c). A 2M solution of $\mathrm{NaOH}(1.9 \mathrm{~mL}, 3.8 \mathrm{mmol}, 1$ eq.) was added dropwise to a solution of benzaldehyde $16(750 \mathrm{mg}, 3.8 \mathrm{mmol}, 1 \mathrm{eq}$.$) and propanal$ ( $0.50 \mathrm{~mL}, 5.7 \mathrm{mmol}, 1.5$ eq.) in $\mathrm{MeOH}(15 \mathrm{~mL})$, at rt. The reaction was allowed to stir at $50{ }^{\circ} \mathrm{C}$ overnight. After that time it was quenched with
$\mathrm{NH}_{4} \mathrm{Cl}$ and then extracted with DCM $(3 \times 50 \mathrm{~mL})$. The combined organic layers were dried over $\mathrm{Na}_{2} \mathrm{SO}_{4}$ and concentrated in vacuo to yield cinnamaldehyde 11b (630 mg, 70\% yield). ${ }^{1} \mathrm{H}$ NMR (400 MHz, $\mathrm{CDCl}_{3}$ ): $\delta_{\mathrm{H}}$ $1.92(\mathrm{~s}, 3 \mathrm{H}) ; 2.47(\mathrm{~s}, 3 \mathrm{H}) ; 7.20-7.22(\mathrm{~m}, 1 \mathrm{H}) ; 7.25-7.27(\mathrm{~m}, 2 \mathrm{H}) ; 7.50(\mathrm{~s}$ $1 \mathrm{H}) ; 9.69(\mathrm{~s}, 1 \mathrm{H}) ;{ }^{13} \mathrm{C}$ NMR $\left(100 \mathrm{MHz}, \mathrm{CDCl}_{3}\right)$; $\delta_{\mathrm{C}} 10.7\left(\mathrm{CH}_{3}\right), 23.6\left(\mathrm{CH}_{3}\right)$, $126.6(\mathrm{C}), 126.7(\mathrm{CH}), 127.8(\mathrm{CH}), 131.2(\mathrm{CH}), 135.5(\mathrm{C}), 139.1(\mathrm{C})$ $139.5(\mathrm{C}), 149.1(\mathrm{CH}), 195.3(\mathrm{CH})$; IR: v 3049, 2954, 2922, 2819, 2710, 1686, 1629, 1572, 1445, 14411, 1385, 1355, 1264, 1186, 1027, 1005 935, 866, 834, 789, 771, 723, $681 \mathrm{~cm}^{-1}$; HRMS (ESI) 239.0054 and $241.0034\left(\mathrm{C}_{11} \mathrm{H}_{11}{ }^{79} \mathrm{BrO}\right.$ and $\mathrm{C}_{11} \mathrm{H}_{11}{ }^{81} \mathrm{BrO}[\mathrm{M}+\mathrm{H}]^{+}$requires 239.0066 and 241.0046).

(-)-(3R,4S,E)-1-(2-bromo-3-methylphenyl)-2,4-dimethlhexa-1,5-dien3-ol (9c). A $100 \mathrm{~mL}$ round bottom flask fitted with a magnetic stirring bar was flame-dried, evacuated and backfilled with $\mathrm{N}_{2}$. The flask was charged with $30 \mathrm{~mL}$ of dry propionitrile and successively with a solution of bis- $N$-oxide (-)-12 (80.4 mg, $0.1 \mathrm{mmol}, 2 \mathrm{~mol} \%$ ), aldehyde $11 \mathrm{~b}$ (1.25 g, $5.2 \mathrm{mmol}, 1$ eq.) and Hünig's base ( $1.8 \mathrm{~mL}, 10.3 \mathrm{mmol}, 2$ eq.) in $1 \mathrm{~mL}$ of dry propionitrile each. The solution was cooled at $-60^{\circ} \mathrm{C}$ and a solution of Z-crotyltrichlorosilane $10(1.7 \mathrm{~g}, 8.9 \mathrm{mmol}, 1.7 \mathrm{eq}$.$) in 1 \mathrm{~mL}$ of dry propionitrile was added dropwise to the reaction mixture. The mixture was stirred at this temperature for two days. After that time, it was quenched with a saturated solution of $\mathrm{NaHCO}_{3}(10 \mathrm{~mL})$, washed with 20 $\mathrm{mL}$ of $\mathrm{NaHCO}_{3}$ and extracted with DCM $(3 \times 60 \mathrm{~mL})$. Combined organic layers were dried over $\mathrm{Na}_{2} \mathrm{SO}_{4}$ and solvent was removed in vacuo. Flash chromatography on silica with a gradient eluent system (100\% hexane to 95:5, hexane/ethyl acetate) afforded the target homoallylic alcohol (-)-9b as a colourless oil (1.10 g, $72 \%$ yield). ${ }^{1} \mathrm{H}$ NMR $\left(400 \mathrm{MHz}, \mathrm{CDCl}_{3}\right): \delta_{\mathrm{H}}$ $1.13(\mathrm{~d}, \mathrm{~J}=6.8 \mathrm{~Hz}, 3 \mathrm{H}) ; 1.70(\mathrm{~s}, 3 \mathrm{H}) ; 1.73$ (s broad, $1 \mathrm{H}) ; 2.43(\mathrm{~s}, 3 \mathrm{H}) ; 2.53$ $(\mathrm{q}, \mathrm{J}=6.8 \mathrm{~Hz}, 1 \mathrm{H}) ; 4.08(\mathrm{~d}, \mathrm{~J}=6.4 \mathrm{~Hz}, 1 \mathrm{H}) ; 5.06-5.15(\mathrm{~m}, 2 \mathrm{H}) ; 5.83-5.91$ $(\mathrm{m}, 1 \mathrm{H}) ; 6.53(\mathrm{~s}, 1 \mathrm{H}) ; 7.04-7.06(\mathrm{~m}, 1 \mathrm{H}) ; 7.11-7.17(\mathrm{~m}, 2 \mathrm{H}) ;{ }^{13} \mathrm{C}$ NMR $\left(100 \mathrm{MHz}, \mathrm{CDCl}_{3}\right): \delta_{\mathrm{C}} 13.9\left(\mathrm{CH}_{3}\right), 14.4\left(\mathrm{CH}_{3}\right), 23.7\left(\mathrm{CH}_{3}\right), 41.4(\mathrm{CH}), 80.0$ $(\mathrm{CH}), 114.7\left(\mathrm{CH}_{2}\right), 126.3(\mathrm{CH}), 126.7(\mathrm{C}), 127.1(\mathrm{CH}), 128.2(\mathrm{CH}), 128.9$ $(\mathrm{CH}), 138.3(\mathrm{C}), 138.3(\mathrm{C}), 139.5(\mathrm{C}), 140.9(\mathrm{CH})$; IR: v3412, 3069, 2975, 2923, 2870, 1640, 1586, 1463, 1449, 1401, 1379, 1228, 1107, 1024, 913, $791,767,725 \mathrm{~cm}^{-1}$; HRMS (ESI) 400.9666 and $402.9651\left(\mathrm{C}_{15} \mathrm{H}_{19}{ }^{79} \mathrm{BrO}\right.$ and $\mathrm{C}_{15} \mathrm{H}_{19}{ }^{81} \mathrm{BrO}[\mathrm{M}+\mathrm{Ag}]^{+}$requires 400.9665 and 402.9644).; Chiral HPLC (Chiralpak IA-3, hexane/2-propanol $=98: 2,0.75 \mathrm{~mL} / \mathrm{min}$, UV detection at $225 \mathrm{~nm}$ ) showed 99:1 er ( $t_{\mathrm{R}}=19.3 \mathrm{~min}$ (major), $t_{\mathrm{S}}=20.8 \mathrm{~min}$ (minor)). $[\alpha]_{D}^{25}=-27\left(\right.$ c $\left.6.5, \mathrm{CHCl}_{3}\right)$

In a racemic variant, $Z$-crotyltrichlorosilane $9 \mathrm{c}(1.0 \mathrm{~g}, 5.00 \mathrm{mmol})$ was added to a solution of $11 \mathrm{c}$ (75 mg, $0.31 \mathrm{mmol}, 1$ eq.) in DMF (5 mL) and Hünig's base (108 $\mu \mathrm{L}, 0.62 \mathrm{mmol}, 2$ eq.) under $\mathrm{N}_{2}$ atmosphere. The reaction mixture was stirred and monitored by TLC until completion. Then it was quenched with saturated $\mathrm{NaHCO}_{3}(10 \mathrm{~mL})$ and extracted with ethyl acetate $(3 \times 20 \mathrm{~mL})$. The organic layers were dried over $\mathrm{Na}_{2} \mathrm{SO}_{4}$ and concentrated in vacuo. Flash chromatography on silica with a gradient eluent system (100\% hexane to $95: 5$, hexane/ethyl acetate) afforded the target homoallylic alcohol $( \pm)-9 \mathrm{c}$ as a colourless oil $(78 \mathrm{mg}, 85 \%)$.

(2E,4R,5S,7E)-ethyl 5-(2-bromo-3-methylphenyl)-4-methylnona-2,7dienoate (15c). A $30 \%$ suspension of $\mathrm{KH}$ in mineral oil $(2.2 \mathrm{~g}, 55.5 \mathrm{mmol}$, 15 eq.) was washed with anhydrous DME $(3 \times 10 \mathrm{~mL})$. Anhydrous DME $(45 \mathrm{~mL})$ was added to the $\mathrm{KH}$. Alcohol $(-)-9 \mathrm{c}(1.10 \mathrm{~g}, 3.7 \mathrm{mmol}, 1 \mathrm{eq}$.) and 18-crown-6 (0.97 g, $3.7 \mathrm{mmol}, 1$ eq.) were successively added to the solution and the mixture was stirred for two days at rt. The solution was cooled to $-78{ }^{\circ} \mathrm{C}$ and quenched with a $1 \mathrm{M}$ solution of 2,4,6-tri-tertbutylphenol in dry DME (7eq). The solution was poured into a saturated solution of $\mathrm{NH}_{4} \mathrm{Cl}(50 \mathrm{~mL})$ and extracted with $\mathrm{DCM}(3 \times 50 \mathrm{~mL})$. The combined organic layers were dried over $\mathrm{Na}_{2} \mathrm{SO}_{4}$ and concentrated in vacuo. The resulting crude aldehyde obtained as a yellow oil was used immediately in the next step. 
$\mathrm{LiCl}$ (186.5 mg, $4.44 \mathrm{mmol}, 1.2$ eq.) was weighted in a $50 \mathrm{~mL}$ flame-dried round bottom flask. The flask was evacuated and backfilled with $\mathrm{N}_{2}$. Dry $\mathrm{CH}_{3} \mathrm{CN}(10 \mathrm{~mL})$ was added followed by a solution of Hünig's base $(0.8$ $\mathrm{mL}, 4.44 \mathrm{mmol}, 1.2$ eq.) and triethyl phosphonoacetate $(0.9 \mathrm{~mL}, 4.44$ mmol, 1.2 eq.) in $2 \mathrm{~mL}$ of dry $\mathrm{CH}_{3} \mathrm{CN}$ each. After stirring the mixture for 5 minutes, the crude aldehyde ( $3.7 \mathrm{mmol}, 1$ eq.) in $2 \mathrm{~mL}$ of anhydrous $\mathrm{CH}_{3} \mathrm{CN}$ was added dropwise. The reaction mixture was stirred overnight at $\mathrm{rt}$ and after that time it was quenching with a saturated solution of $\mathrm{NH}_{4} \mathrm{Cl}(20 \mathrm{~mL})$. The mixture was extracted with DCM $(3 \times 50 \mathrm{~mL})$, the organic phases dried over $\mathrm{Na}_{2} \mathrm{SO}_{4}$ and the solvents removed under reduced pressure. The crude mixture was purified by flash column chromatography on silica eluting with a gradient system (100\% petroleum ether to 5:1 petroleum ether/ethyl acetate) to yield $15 \mathrm{c}(\mathrm{dr} 2: 1)$ as a colourless oil ( $1.1 \mathrm{~g}, 81 \%$ yield over two steps).

Major isomer (taken as a mixture): ${ }^{1} \mathrm{H}$ NMR (400 MHz, $\left.\mathrm{CDCl}_{3}\right): \delta_{\mathrm{H}} 1.01$ (d $\mathrm{J}=6.8 \mathrm{~Hz}, 3 \mathrm{H}) ; 1.27(\mathrm{t}, \mathrm{J}=6.8 \mathrm{~Hz}, 3 \mathrm{H}) ; 1.53(\mathrm{~d}, 6.4 \mathrm{~Hz}, 3 \mathrm{H}) ; 2.37-3.33(\mathrm{~m}$ $2 \mathrm{H}) ; 2.43(\mathrm{~s}, 3 \mathrm{H}) ; 2.68-2.71(\mathrm{~m}, 1 \mathrm{H}) ; 3.49-3.53(\mathrm{~m}, 1 \mathrm{H}) ; 4.14-4.23(\mathrm{~m}$, $2 \mathrm{H}) ; 5.11-5.41(\mathrm{~m}, 2 \mathrm{H}) ; 5.74(\mathrm{~d}, \mathrm{~J}=15.6 \mathrm{~Hz}, 1 \mathrm{H}) ; 6.92-7.01(\mathrm{~m}, 2 \mathrm{H}) ; 7.06-$ $7.17(\mathrm{~m}, 2 \mathrm{H})$.

Minor isomer (taken as a mixture): ${ }^{1} \mathrm{H}$ NMR $\left(400 \mathrm{MHz}, \mathrm{CDCl}_{3}\right): \delta_{\mathrm{H}} 0.91(\mathrm{~d}$ $\mathrm{J}=6.4 \mathrm{~Hz}, 3 \mathrm{H}) ; 1.31(\mathrm{t}, \mathrm{J}=7.2 \mathrm{~Hz}, 3 \mathrm{H}) ; 1.49(\mathrm{~d}, \mathrm{~J}=6.4 \mathrm{~Hz}, 3 \mathrm{H}) ; 2.37-3.33$ $(\mathrm{m}, 2 \mathrm{H}) ; 2.44(\mathrm{~s}, 3 \mathrm{H}) ; 2.49-2.53(\mathrm{~m}, 1 \mathrm{H}) ; 3.38-3.41(\mathrm{~m}, 1 \mathrm{H}) ; 4.14-4.23(\mathrm{~m}$, $2 \mathrm{H}) ; 5.11-5.41(\mathrm{~m}, 2 \mathrm{H}) ; 5.82(\mathrm{~d}, \mathrm{~J}=14.8 \mathrm{~Hz}, 1 \mathrm{H}) ; 6.92-7.01(\mathrm{~m}, 2 \mathrm{H}) ; 7.06-$ $7.17(\mathrm{~m}, 2 \mathrm{H})$.

$(R, E)$-ethyl $\quad$ 4-((1S,4R)-8-bromo-4,7-dimethyl-1,2,3,4-tetrahydronaphthalen-1-yl)pent-2-enoate (16c). Methanesulfonic acid $(0.37 \mathrm{~mL}$ $5.7 \mathrm{mmol}, 3$ eq.) was added to a solution of $15 \mathrm{c}(693 \mathrm{mg}, 1.9 \mathrm{mmol}, 1$ eq. ) in $\mathrm{CHCl}_{3}(3 \mathrm{~mL})$ and the reaction mixture was stirred at $40{ }^{\circ} \mathrm{C}$ for two days. The reaction was quenched with saturated $\mathrm{NaHCO}_{3}(5 \mathrm{~mL})$ and extracted with $\mathrm{CH}_{2} \mathrm{Cl}_{2}(3 \times 20 \mathrm{~mL})$. The combined organic layers were dried over $\mathrm{Na}_{2} \mathrm{SO}_{4}$ and concentrated in vacuo. Purification by column chromatography on silica (eluting with 95:5 petroleum ether/ethyl acetate) gave the title compound 16c (dr 2:1) as a pale yellow oil (570 mg, $83 \%$ yield);

Major isomer (taken as a mixture): ${ }^{1} \mathrm{H}$ NMR $\left(400 \mathrm{MHz}, \mathrm{CDCl}_{3}\right): \delta_{\mathrm{H}} 0.89(\mathrm{~d}$ $\mathrm{J}=6.8 \mathrm{~Hz}, 3 \mathrm{H}) ; 1.21-1.31(\mathrm{~m}, 6 \mathrm{H}) ; 1.74-1.95(\mathrm{~m}, 4 \mathrm{H}) ; 2.38(\mathrm{~s}, 3 \mathrm{H}) ; 2.74-$ $2.79(\mathrm{~m}, 1 \mathrm{H}) ; 3.04-3.09(\mathrm{~m}, 1 \mathrm{H}) ; 3.49-3.53(\mathrm{~m}, 1 \mathrm{H}) ; 4.12-4.4 .21(\mathrm{~m}, 2 \mathrm{H})$; $5.74(\mathrm{dd}, \mathrm{J}=16,1.6 \mathrm{~Hz}, 1 \mathrm{H}) ; 7.06-7.12(\mathrm{~m}, 3 \mathrm{H}) ;{ }^{13} \mathrm{C} \mathrm{NMR}(100 \mathrm{MHz}$, $\left.\mathrm{CDCl}_{3}\right): \delta_{\mathrm{C}} 14.2\left(\mathrm{CH}_{3}\right), 14.2\left(\mathrm{CH}_{3}\right), 16.9\left(\mathrm{CH}_{3}\right), 21.5\left(\mathrm{CH}_{2}\right), 22.3(\mathrm{CH})$ $24.2\left(\mathrm{CH}_{3}\right), 29.2\left(\mathrm{CH}_{2}\right), 32.2(\mathrm{CH}), 39.6(\mathrm{CH}), 41.7(\mathrm{CH}), 60.1\left(\mathrm{CH}_{2}\right)$ $120.0(\mathrm{CH}), 125.4(\mathrm{CH}), 128.2(\mathrm{CH}), 136.1(\mathrm{C}), 137.8(\mathrm{C}), 143.4(\mathrm{C})$, $153.3(\mathrm{CH}), 166.8(\mathrm{C})$

Minor isomer (taken as a mixture): ${ }^{1} \mathrm{H}$ NMR $\left(400 \mathrm{MHz}, \mathrm{CDCl}_{3}\right): \delta_{\mathrm{H}} 0.90(\mathrm{~d}$ $J=6.8 \mathrm{~Hz}, 3 \mathrm{H}) ; 1.15(\mathrm{~d}, \mathrm{~J}=7.2 \mathrm{~Hz}, 3 \mathrm{H}) ; 1.21-1.31(\mathrm{~m}, 3 \mathrm{H}) ; 1.74-1.95(\mathrm{~m}$, $4 \mathrm{H}) ; 2.41(\mathrm{~s}, 3 \mathrm{H}) ; 2.74-2.79(\mathrm{~m}, 1 \mathrm{H}) ; 2.97-3.00(\mathrm{~m}, 1 \mathrm{H}) ; 3.40-3.44$ $(\mathrm{m}, 1 \mathrm{H}) ; 4.12-4.21(\mathrm{~m}, 2 \mathrm{H}) ; 5.64(\mathrm{dd}, \mathrm{J}=15.6,1.6 \mathrm{~Hz}, 1 \mathrm{H}), 6.79$ (dd, $\mathrm{J}=$ 15.6, 6.4Hz, $1 \mathrm{H}) ; 7.06-7.07(\mathrm{~m}, 2 \mathrm{H}) ;{ }^{13} \mathrm{C}$ NMR (100 MHz, $\left.\mathrm{CDCl}_{3}\right): \delta_{\mathrm{C}} 14.2$ $\left(\mathrm{CH}_{3}\right), 14.3\left(\mathrm{CH}_{3}\right), 16.9\left(\mathrm{CH}_{3}\right), 21.1\left(\mathrm{CH}_{2}\right), 22.6(\mathrm{CH}), 24.2\left(\mathrm{CH}_{3}\right), 28.5$ $\left(\mathrm{CH}_{2}\right), 31.8(\mathrm{CH}), 40.0(\mathrm{CH}), 42.7(\mathrm{CH}), 60.0\left(\mathrm{CH}_{2}\right), 120.0(\mathrm{CH}), 125.7$ $(\mathrm{CH}), 128.4(\mathrm{CH}), 136.0(\mathrm{C}), 138.1(\mathrm{C}), 143.1(\mathrm{C}), 152.6(\mathrm{CH}), 166.6(\mathrm{C})$.

\section{(-)-(R)-4-((1S,4R)-4,7-dimethyl-1,2,3,4-tetrahydronaphthalen-1-} yl)pentan-1-ol (7) and (-)-(S)-4-((1S,4R)-4,7-dimethyl-1,2,3,4tetrahydronaphthalen-1-yl)pentan-1-ol (7a). A solution of unsaturated ester 16c (458 mg, $1.36 \mathrm{mmol}, 1$ eq.) in $\mathrm{MeOH}$ (35 mL) was circulated for $4 \mathrm{~h}$ through an $\mathrm{H}$-Cube reactor (set at $2.0 \mathrm{~mL} / \mathrm{min}, 20 \mathrm{bar}, 40{ }^{\circ} \mathrm{C}$ ) equipped with a cartridge containing catalyst $10 \% \mathrm{Pd} / \mathrm{C}$. Analysis of an aliquote taken from the mixture showed that hydrogenation of the double bond and debromination were complete. The solvent was removed in vacuo, the residue was dissolved in anhydrous $\mathrm{CH}_{2} \mathrm{Cl}_{2}(20 \mathrm{~mL})$ and cooled to $-78{ }^{\circ} \mathrm{C}$. DIBAL, $1 \mathrm{M}$ in hexanes $(2.2 \mathrm{~mL}, 2.2 \mathrm{mmol})$, was added and the solution was allowed to warm to room temperature and stirred overnight. The reaction was quenched with $\mathrm{MeOH}(10 \mathrm{~mL}), 5 \mathrm{M} \mathrm{HCl}(15$ $\mathrm{mL})$ and extracted with $\mathrm{CH}_{2} \mathrm{Cl}_{2}(3 \times 30 \mathrm{~mL})$. The organic layer were combined, dried over $\mathrm{Na}_{2} \mathrm{SO}_{4}$ and concentrated in vacuo. The crude reaction mixture was filtered through a pad of silica. Removal of solvent in vacuo afforded product 7 ( $\mathrm{dr} 2: 1$ ) as a colourless oil (235 mg, $70 \%$ ). The diastereoisomers 11-epi-7a and 7 were separated in order of elution by

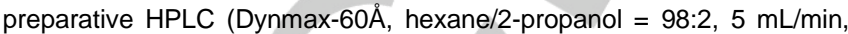
UV detection at $220 \mathrm{~nm}$ ).

Major isomer (-)-7 (104 mg): ${ }^{1} \mathrm{H}$ NMR $\left(400 \mathrm{MHz}, \mathrm{CDCl}_{3}\right): \delta_{\mathrm{H}} 0.65(\mathrm{~d}, \mathrm{~J}=$ $5.2 \mathrm{~Hz}, 3 \mathrm{H}) ; 1.26(\mathrm{~d}, \mathrm{~J}=5.6 \mathrm{~Hz}, 3 \mathrm{H}) ; 1.31-1.38(\mathrm{~m}, 3 \mathrm{H}) ; 1.61-1.70(\mathrm{~m}, 3 \mathrm{H})$ 1.78-1.84 (m, 1H); 1.90-1.95 (m, 1H); 2.13-2.16 (m, 1H); $2.30(\mathrm{~s}, 3 \mathrm{H})$; 2.71-2.75 (m, $1 \mathrm{H}) ; 2.87-2.91(\mathrm{~m}, 1 \mathrm{H}) ; 3.70(\mathrm{t}, \mathrm{J}=5.2 \mathrm{~Hz}, 2 \mathrm{H}) ; 6.95(\mathrm{~d}, \mathrm{~J}=$ $6.4 \mathrm{~Hz}, 1 \mathrm{H}) ; 7.03(\mathrm{~s}, 1 \mathrm{H}) ; 7.14(\mathrm{~d}, \mathrm{~J}=6 \mathrm{~Hz}, 1 \mathrm{H}) ;{ }^{13} \mathrm{C} \mathrm{NMR}(100 \mathrm{MHz}$ $\left.\mathrm{CDCl}_{3}\right): \delta_{\mathrm{C}} 14.5\left(\mathrm{CH}_{3}\right), 21.1\left(\mathrm{CH}_{3}\right), 21.5\left(\mathrm{CH}_{2}\right), 21.8\left(\mathrm{CH}_{3}\right), 31.1\left(\mathrm{CH}_{2}\right)$ $31.6\left(\mathrm{CH}_{2}\right), 32.8(\mathrm{CH}), 37.1(\mathrm{CH}), 41.6(\mathrm{CH}), 63.4\left(\mathrm{CH}_{2}\right), 126.0(\mathrm{CH})$, $126.4(\mathrm{CH}), 128.0(\mathrm{CH}), 134.7(\mathrm{C}), 139.6(\mathrm{C}), 140.3(\mathrm{C})$; IR: $v$ 3343, 2928, 2869, 1497, 1455, 1376, 1058, $812 \mathrm{~cm}^{-1}$; HRMS (ESI) 353.1037 $\left(\mathrm{C}_{17} \mathrm{H}_{26} \mathrm{O}^{107} \mathrm{Ag}[\mathrm{M}]^{+}\right.$required 353.1029). $[\alpha]_{D}^{25}=-54.5$ (c 1.02, $\left.\mathrm{CHCl}_{3}\right)$; lit. for $(+)-7[\alpha]_{D}^{25}=+36.5\left(\mathrm{c} 0.81, \mathrm{CHCl}_{3}\right) .^{[5 c]}$

Minor isomer (-)-7a (65 mg): ${ }^{1} \mathrm{H}$ NMR $\left(400 \mathrm{MHz}, \mathrm{CDCl}_{3}\right): \delta_{\mathrm{H}} 1.03(\mathrm{~d}, \mathrm{~J}=$ $6.8 \mathrm{~Hz}, 3 \mathrm{H}) ; 1.28(\mathrm{~d}, \mathrm{~J}=6.8 \mathrm{~Hz}, 3 \mathrm{H}) ; 1.33-1.39(\mathrm{~m}, 2 \mathrm{H}) ; 1.47$ ( $\left.\mathrm{s}_{\text {broad }}, 1 \mathrm{H}\right)$; $1.55-1.60(\mathrm{~m}, 3 \mathrm{H}) ; 1.89-1.94(\mathrm{~m}, 2 \mathrm{H}) ; 2.08-2.13(\mathrm{~m}, 1 \mathrm{H}) ; 2.32(\mathrm{~s}, 3 \mathrm{H})$ 2.75-2.81 (m, 2H); 3.48-3.56 (m, 2H); $6.96(\mathrm{~d}, \mathrm{~J}=8 \mathrm{~Hz}, 1 \mathrm{H}) ; 7.04(\mathrm{~s}, 1 \mathrm{H})$; $7.15(\mathrm{~d}, \mathrm{~J}=8 \mathrm{~Hz}, 1 \mathrm{H}) ;{ }^{13} \mathrm{C}$ NMR $\left(100 \mathrm{MHz}, \mathrm{CDCl}_{3}\right): \delta_{\mathrm{C}} 140.3(\mathrm{C}), 139.6$ $(\mathrm{C}), 134.6(\mathrm{C}), 128.2(\mathrm{CH}), 126.8(\mathrm{CH}), 126.2(\mathrm{CH}), 63.1\left(\mathrm{CH}_{2}\right), 43.7$ $(\mathrm{CH}), 36.9(\mathrm{CH}), 32.7(\mathrm{CH}), 31.2\left(\mathrm{CH}_{2}\right), 31.1\left(\mathrm{CH}_{2}\right), 27.3\left(\mathrm{CH}_{2}\right), 22.2$ $\left(\mathrm{CH}_{2}\right), 22.1\left(\mathrm{CH}_{3}\right), 21.1\left(\mathrm{CH}_{3}\right), 18.2\left(\mathrm{CH}_{3}\right)$; IR: $v$ 3343, 2928, 2869, 1497, 1455, 1376, 1058, $812 \mathrm{~cm}^{-1}$; HRMS (ESI) $353.1037\left(\mathrm{C}_{17} \mathrm{H}_{26} \mathrm{O}^{107} \mathrm{Ag}[\mathrm{M}]^{+}\right.$ required 353.1029). $[\alpha]_{D}^{25}=-32.9\left(c \quad 0.41, \mathrm{CHCl}_{3}\right)$. $[\alpha]_{D}^{25}=-54.5(c$ 1.02, $\left.\mathrm{CHCl}_{3}\right)$; lit. for (+)-7 $[\alpha]_{\mathrm{D}}{ }^{25}=+36.5\left(\mathrm{c} 0.81, \mathrm{CHCl}_{3}\right)$. ${ }^{[5 \mathrm{c}]}$

(-)-(1R,4S)-1,6-dimethyl-4-((R)-6-methylhept-5-en-2-yl)-1,2,3,4tetrahydronaphthalene. (-)-Erogorgiaene (1)

Dess-Martin periodinane (1.5 eq.) was weighted in a $25 \mathrm{~mL}$ flame-dried round bottom flask. The vessel was evacuated and backfilled with $\mathrm{N}_{2}$ before being charged with alcohol 7 (104 mg, 1 eq.) in $5 \mathrm{~mL}$ of DCM. The reaction was allowed to stir at room temperature for 2 hours. The solvent was partially removed in vacuo and the crude mixture was directly purified by flash column chromatography on silica using a 95:5 mixture of petroleum ether/ethyl acetate as an eluent. After removal of solvent in vacuo, the resulting aldehyde as pale yellow oil $(86 \mathrm{mg}, 84 \%)$ was used in the next step.

$n$ BuLi, $1.6 \mathrm{M}$ solution in hexane $(0.5 \mathrm{~mL}, 0.81 \mathrm{mmol}, 3$ eq.), was added dropwise to a solution of isopropyltriphenylphosphonium iodide (385.2 $\mathrm{mg}, 0.89 \mathrm{mmol})$ in anhydrous THF $(3 \mathrm{~mL})$ at $0{ }^{\circ} \mathrm{C}$ under $\mathrm{N}_{2}$. The mixture was stirred for $1 \mathrm{~h}$ and then a solution of the aliphatic aldehyde from the step above (65 mg, $1.3 \mathrm{mmol})$ in THF $(15 \mathrm{~mL})$ was added. The solution was allowed to stir at the same temperature for 30 minutes before warming to rt and heating at reflux for a further $2 \mathrm{~h}$. After cooling, the reaction mixture was quenched with saturated $\mathrm{NH}_{4} \mathrm{Cl}(5 \mathrm{~mL})$ and extracted with $\mathrm{DCM}(3 \times 20 \mathrm{~mL})$. The organic layers were combined, dried over $\mathrm{Na}_{2} \mathrm{SO}_{4}$ and concentrated in vacuo. Purification by column chromatography on silica (10:1 petroleum ether/ethyl acetate) gave (-)-erogorgiaene 1 as a colourless oil (58 mg, $80 \%$, or $67 \%$ over two steps). ${ }^{1} \mathrm{H}$ NMR $(400 \mathrm{MHz}$, $\left.\mathrm{CDCl}_{3}\right): \delta_{\mathrm{H}} 0.66(\mathrm{~d}, \mathrm{~J}=6.8 \mathrm{~Hz}, 3 \mathrm{H}) ; 1.29(\mathrm{~d}, \mathrm{~J}=6.8 \mathrm{~Hz}, 3 \mathrm{H}) ; 1.32-1.41(\mathrm{~m}$, $2 \mathrm{H})$; $1.45-1.57(\mathrm{~m}, 2 \mathrm{H}) ; 1.67(\mathrm{~s}, 3 \mathrm{H}) ; 1.75(\mathrm{~s}, 3 \mathrm{H}) ; 1.80-1.87(\mathrm{~m}, 1 \mathrm{H})$; 
1.91-1.97 (m, 1H); 2.04-2.19 (m, 3H); $2.33(\mathrm{~s}, 3 \mathrm{H}) ; 2.72-2.76(\mathrm{~m}, 1 \mathrm{H})$ 2.88-2.93 (m, 1H); $5.20(\mathrm{tm}, J=6.8 \mathrm{~Hz}, 1 \mathrm{H}) ; 6.97(\mathrm{~d}, \mathrm{~J}=8 \mathrm{~Hz}, 1 \mathrm{H}) ; 7.05$ $(\mathrm{s}, 1 \mathrm{H}) ; 7.16(\mathrm{~d}, \mathrm{~J}=8 \mathrm{~Hz}, 1 \mathrm{H}) ;{ }^{13} \mathrm{C}$ NMR $\left(100 \mathrm{MHz}, \mathrm{CDCl}_{3}\right): \delta_{\mathrm{C}} 14.5\left(\mathrm{CH}_{3}\right)$, $17.7\left(\mathrm{CH}_{3}\right), 21.1\left(\mathrm{CH}_{3}\right), 21.5\left(\mathrm{CH}_{2}\right), 21.8\left(\mathrm{CH}_{3}\right), 25.7\left(\mathrm{CH}_{3}\right), 26.3\left(\mathrm{CH}_{2}\right)$, $31.8\left(\mathrm{CH}_{2}\right), 32.8(\mathrm{CH}), 35.2\left(\mathrm{CH}_{2}\right), 36.9(\mathrm{CH}), 41.4(\mathrm{CH}), 124.9(\mathrm{CH})$, $126.0(\mathrm{CH}), 126.4(\mathrm{CH}), 128.1(\mathrm{CH}), 131.2(\mathrm{C}), 134.7(\mathrm{C}), 139.9(\mathrm{C})$, 140.4 (C); IR: $v$ 2959, 2924, 2853, 1613, 1497, 1452, 1376, 1320, 1109 1039, 983, 881, $811 \mathrm{~cm}^{-1}$; HRMS (ESI) 377.1390 and 379.1386 $\left(\mathrm{C}_{20} \mathrm{H}_{30}{ }^{107} \mathrm{Ag}[\mathrm{M}+\mathrm{Ag}]^{+}\right.$requires 377.1393 and $\mathrm{C}_{20} \mathrm{H}_{30}{ }^{109} \mathrm{Ag}[\mathrm{M}+\mathrm{Ag}]^{+}$re-

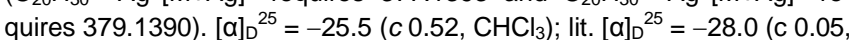
$\left.\mathrm{CHCl}_{3}\right) ;{ }^{[2]}$ lit. for $(+)-1:[\alpha]_{\mathrm{D}}{ }^{25}=+24.4\left(\mathrm{c} \mathrm{3.20}, \mathrm{CHCl}_{3}\right) ;{ }^{[1 \mathrm{a}]}[\mathrm{\alpha}]_{\mathrm{D}}{ }^{25}=+23.2$ (c $\left.0.75, \mathrm{CHCl}_{3}\right) ;{ }^{[3 \mathrm{c}]}[\mathrm{\alpha}]_{\mathrm{D}}{ }^{25}=+69.1(\mathrm{c} 0.77, \mathrm{DCM}) ;^{[4 \mathrm{~b}]}[\mathrm{\alpha}]_{\mathrm{D}}{ }^{25}=+40.6$ (c 0.14 , $\left.\mathrm{CHCl}_{3}\right){ }^{[5 \mathrm{a}]}[\mathrm{a}]_{\mathrm{D}}{ }^{25}=+21.4\left(\mathrm{c} 0.14, \mathrm{CHCl}_{3}\right) .{ }^{[5 \mathrm{c}]}$

\section{(-)-(1R,4S)-1,6-dimethyl-4-((S)-6-methylhept-5-en-2-yl)-1,2,3,4- tetrahydronaphthalene (1a).}

Diastereoisomer (-)-1a was obtained from (-)-7a using the same sequence as described for (-)-1 as a colourless oil (15 mg, 30\% from 7a): ${ }^{1} \mathrm{H}$ NMR $\left(400 \mathrm{MHz}, \mathrm{CDCl}_{3}\right): \delta_{\mathrm{H}} 1.00(\mathrm{~d}, \mathrm{~J}=6.8 \mathrm{~Hz}, 3 \mathrm{H}) ; 1.23-1.27(\mathrm{~m}$, $7 \mathrm{H}) ; 1.55(\mathrm{~s}, 3 \mathrm{H}) ; 1.66(\mathrm{~s}, 3 \mathrm{H}) ; 1.80-2.00(\mathrm{~m}, 4 \mathrm{H}) ; 2.07-2.12(\mathrm{~m}, 2 \mathrm{H}) ; 2.30$ (s, 3H); 2.73-2.77 (m, 2H); $4.98(\mathrm{t}, \mathrm{J}=7.4 \mathrm{~Hz}, 1 \mathrm{H}) ; 6.94(\mathrm{~m}, 1 \mathrm{H}) ; 7.03(\mathrm{~s}$, $1 \mathrm{H}) ; 7.13(\mathrm{~d}, \mathrm{~J}=8 \mathrm{~Hz}, 1 \mathrm{H}) ;{ }^{13} \mathrm{C}$ NMR $\left(100 \mathrm{MHz}, \mathrm{CDCl}_{3}\right): \delta_{\mathrm{C}} 17.6\left(\mathrm{CH}_{3}\right)$, $18.1\left(\mathrm{CH}_{3}\right), 21.1\left(\mathrm{CH}_{3}\right), 22.2\left(\mathrm{CH}_{3}\right), 22.4\left(\mathrm{CH}_{2}\right), 25.7\left(\mathrm{CH}_{3}\right), 26.3\left(\mathrm{CH}_{2}\right)$ $31.4\left(\mathrm{CH}_{2}\right), 31.5\left(\mathrm{CH}_{2}\right), 32.7(\mathrm{CH}), 36.2(\mathrm{CH}), 43.8(\mathrm{CH}), 125.0(\mathrm{CH})$, $126.1(\mathrm{CH}), 126.7(\mathrm{CH}), 128.4(\mathrm{CH}), 131.2(\mathrm{C}), 134.5(\mathrm{C}), 139.7(\mathrm{C})$, 140.2 (C). IR: $v$ 2959, 2924, 2853, 1613, 1497, 1452, 1376, 1320, 1109, 1039, 983, 881, $811 \mathrm{~cm}^{-1}$; HRMS (ESI) 377.1390 and 379.1386 $\left(\mathrm{C}_{20} \mathrm{H}_{30}{ }^{107} \mathrm{Ag}[\mathrm{M}+\mathrm{Ag}]^{+}\right.$requires 377.1393 and $\mathrm{C}_{20} \mathrm{H}_{30}{ }^{109} \mathrm{Ag}[\mathrm{M}+\mathrm{Ag}]^{+}$requires 379.1390). $[\alpha]_{\mathrm{D}}{ }^{25}=-25.3\left(c=0.3, \mathrm{CHCl}_{3}\right)$; lit. for $(+)-1 \mathrm{a}:[\alpha]_{\mathrm{D}}^{22}=$ +55.2 (c 0.83, DCM) ${ }^{[4 \mathrm{~b}]}$

\section{Acknowledgements}

The authors thank Russian Science Foundation for grant 15-1300092 and the Loughborough University for studentships to CAIP and PSOH.

Keywords: allylation · asymmetric catalysis· rearrangement · stereoselectivity $\cdot$ total synthesis

[1] a) A. D. Rodriguez, C. Ramirez, J. Nat. Prod. 2001, 64, 100-102; b) M. Donia, M. T. Hamann, Lancet. Infect. Dis. 2003, 3, 338-348; c) C. P. Ndi, S. J. Semple, H. J. Griesser, S. M. Pyke, M. D. Barton, Phytochemistry 2007, 68, 2684-2690; d) H. Correa, F. Aristizabal, C. Duque, R. Kerr, Marine drugs 2011, 9, 334-343; e) O. F. Anakok, C. P. Ndi, M. D. Barton, H. J. Griesser, S. J. Semple, J. Appl. Microbiol. 2012 112, 197-204; f) E. C. Barnes, A. M. Kavanagh, S. Ramu, M. A. Blaskovich, M. A. Cooper, R. A. Davis, Phytochemistry 2013, 93, 162169; g) E. Sansinenea, A. Ortiz, Curr. Org. Synth. 2014, 11, 545-591.

[2] S. A. Kolesnikova, A. I. Kalinovsky, S. N. Fedorov, L. K. Shubina, V. A. Stonik, Phytochemistry 2006, 67, 2115-2119.

[3] a) J. M. H. Lu, M. V. Perkins, H. J. Griesser, Tetrahedron 2013, 69, 6468-6473; b) J. S. Yadav, A. K. Basak, P. Srihari, Tetrahedron Lett.
2007, 48, 2841-2843; c) J. S. Yadav, B. Thirupathaiah, A. Al Khazim Al Ghamdi, Eur. J. Org. Chem. 2012, 2072-2076.

[4] a) F. Dehmel, J. Lex, H. G. Schmalz, Org. Lett. 2002, 4, 3915-3918; b) T. G. Elford, S. Nave, R. P. Sonawane, V. K. Aggarwal, J. Am. Chem. Soc. 2011, 133, 16798-16801; c) M. Harmata, X. Hong, Tetrahedron Lett. 2005, 46, 3847-3849; d) M. Harmata, X. Hong, P. R. Schreiner, J. Org. Chem. 2008, 73, 1290-1296; e) W. Lolsberg, S. Werle, J. M. Neudorfl, H. G. Schmalz, Org. Lett. 2012, 14, 5996-5999.

[5] a) R. R. Cesati lii, J. De Armas, A. H. Hoveyda, J. Am. Chem. Soc 2004, 126, 96-101; b) H. M. L. Davies, X. Dai, Tetrahedron 2006, 62 10477-10484; c) H. M. L. Davies, A. M. Walji, Angew. Chem. 2005, 117, 1761-1763; Angew. Chem. Int. Ed. 2005, 44, 1733-1735; d) P. S O'Hora, C. A. Incerti-Pradillos, M. A. Kabeshov, S. A. Shipilovskikh, A E. Rubtsov, M. R. J. Elsegood, A. V. Malkov, Chem. Eur. J. 2015, 21, 4551-4555; e) X. Yu, F. Su, C. Liu, H. Yuan, S. Zhao, Z. Zhou, T. Quan, T. Luo, J. Am. Chem. Soc. 2016, 138, 6261-6270.

[6] a) S. E. Denmark, J. Fu, M. J. Lawler, J. Org. Chem. 2006, 71, 15231536; b) A. Kadlčíková, I. Valterová, L. Ducháčková, J. Roithová, M Kotora, Chem. Eur. J. 2010, 16, 9442-9445; c) A. V. Malkov, M. Barlóg Y. Jewkes, J. Mikušek, P. Kočovský, J. Org. Chem. 2011, 76, 48004804; d) P. Koukal, J. Ulč, D. Nečas, M. Kotora, Eur. J. Org. Chem. 2016, 2110-2114.

[7] a) L. A. Paquette, Angew. Chem. 1990, 102, 642-660; Angew. Chem. Int. Ed. 1990, 29, 609-626; b) L. A. Paquette, G. D. Maynard, Angew. Chem. 1991, 103, 1392-1394; Angew. Chem. Int. Ed. 1991, 30, 13681370; c) L. A. Paquette, G. D. Maynard, J. Am. Chem. Soc. 1992, 114 5018-5027; d) A. P. Rutherford, R. C. Hartley, Tetrahedron Lett. 2000 41, 737-741; e) H. T. Mamdani, R. C. Hartley, Tetrahedron Lett. 2000, 41, 747-749; f) K. Tomooka, S.-Y. Wei, T. Nakai, Chem. Lett. 1991, 43 46. For recent overviews, see g) E. A. Ilardi, C. E. Stivala, A. Zakarian, Chem. Soc. Rev. 2009, 38, 3133-3148; h) H. M. Davies, Y. Lian, Acc. Chem. Res. 2012, 45, 923-935.

[8] R. Appelbe, M. Casey, A. Dunne, E. Pascarella, Tetrahedron Lett. 2003 44, 7641-7644.

[9] For details of conformational search for the enol form of $\mathbf{8 c}$, see ESI.

[10] a) L. Czollner, W. Frantsits, B. Küenburg, U. Hedenig, J. Fröhlich, U. Jordis, Tetrahedron Lett. 1998, 39, 2087-2088; b) B. Küenburg, L. Czollner, J. Frôhlich, U. Jordis, Org. Process Res. Dev. 1999, 3, 425431.

[11] M. A. Blanchette, W. Choy, J. T. Davis, A. P. Essenfeld, S. Masamune W. R. Roush, T. Sakai, Tetrahedron Lett. 1984, 25, 2183-2186.

[12] a) R. Escarcena, J. Perez-Meseguer, E. del Olmo, B. Alanis-Garza, E. Garza-Gonzalez, R. Salazar-Aranda, N. W. de Torres, Molecules 2015, 20, 7245-7262; b) G. M. Molina-Salinas, V. M. Rivas-Galindo, S. SaidFernandez, D. C. Lankin, M. A. Munoz, P. Joseph-Nathan, G. F. Pauli, N. Waksman, J. Nat. Prod. 2011, 74, 1842-1850; c) J. Perez-Meseguer, E. del Olmo, B. Alanis-Garza, R. Escarcena, E. Garza-Gonzalez, R. Salazar-Aranda, A. San Feliciano, N. W. de Torres, Bioorg. Med. Chem. 2012, 20, 4155-4163.

[13] X. Fan, H. Lv, Y. H. Guan, H. B. Zhu, X. M. Cui, K. Guo, Chem. Commun. 2014, 50, 4119-4122.

[14] J. Carreras, G. Gopakumar, L. G. Gu, A. Gimeno, P. Linowski, J. Petuskova, W. Thiel, M. Alcarazo, J. Am. Chem. Soc. 2013, 135, 18815-18823 
Entry for the Table of Contents (Please choose one layout)

\section{FULL PAPER}

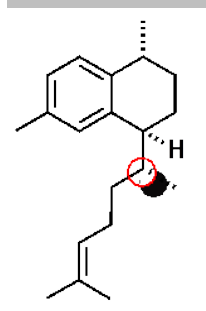

(-)Erogorgiaene<smiles>C=C(CCC=C(C)C)c1cc(C)ccc1CC</smiles>

ey reactions:

1. Catalytic asymmetric allylation

2. Anionic oxy-Cope rearrangement<smiles>C/C=C\C[SiH2]Cl</smiles><smiles>CC(C=O)=Cc1cccc(C)c1Br</smiles>
c11-epimer 3. Cationic cychization

A short, 9-step highly enantioselective synthesis of (-)erogorgiaene and its $\mathrm{C} 11$ epimer is reported. The key stereochemistry control-

ling steps involve catalytic asymmetric crotylation, anionic oxy-Cope rearrangement and cationic cyclisation. (-)-Erogorgiaene exhibited promising antitubercular activity against multidrug resistant strains of $M$. tuberculosis

\section{Diterpenes*}

Celia A. Incerti-Pradillos, Mikhail A. Kabeshov, Paul S. O'Hora, Sergei A. Shipilovskikh, Aleksandr E. Rubtsov, Vera A. Drobkova, Svetlana Yu. Balandina, and Andrei V. Malkov

Page No. - Page No.

Asymmetric Total Synthesis of (-)Erogorgiaene and Its C11 Epimer and Investigation of Their Antimycobacterial Activity 